\title{
The effectiveness of muscle strength exercises in balancing the muscles of the arms and shoulders and their impact on some of the Kinematic variables of straight punches
}

\author{
Dr. Hamada Abdul Aziz Habib ${ }^{1}$, Dr. Mustafa Mohammed Ahmed Nasr ${ }^{2}$
}

\begin{abstract}
Boxing one of the sports which is characterized by specified number of rounds interspersed with short breaks. The boxer performs offensive, defensive and counter-offensive skills from various punching distances; Muscle strength is one of the most important physical elements for boxers. For That the present study aimed to identify the effect of Muscle strength training to balance the muscles of the arms and shoulders and some kinematic variables of straight punches. Methodology: the experimental approach by using the experimental design for one set of pre and post measurement. The research sample was chosen intentionally from young boxing players in Mansoura Stadium, (10) boxing players according to the following table. Measurements: muscular balance was measured using the One Repetition Maximum (1RM) test, Endurance test "striking straight punches on the punching bag $(30 \mathrm{sec}$.) for each arms, Muscular strength of the arms test: throwing the Medical ball $(3 \mathrm{~kg})$ to the furthest distance by the left and right hand, and Kinematic measurements: Performance time, angular displacement, angular velocity for each punch and joint of the elbow and shoulder, In addition, two 250-fps SportsCams were used for 3D Motion Analysis and Simi Motion software was used for kinematographic analysis. The implementation of the training program for a period of 12 weeks The training modules were (6) modules per week. The most important results were that Muscle strength training led to achieve balance in muscle strength of the extensors and flexors muscles of the elbow joint and shoulders. Where the percentage of power to force extensors flexors of the elbow joint and the left and right elbows together (1: 1). High rates of improvement ratios between pre measurement means and post to the research sample in muscle strength of the flexors, reaching $48.3 \%$ of the flexor muscles of the right of the elbow, $(56.7 \%)$ of the muscles flexors of the left elbow, $(24.0 \%)$ of the muscles flexors of the two elbows together. Muscle strength training led to improved kinematic variables under study to straight left and right punches.
\end{abstract}

\section{Introduction :}

Boxing one of the sports which is characterized by specified number of rounds interspersed with short breaks. The boxer performs offensive, defensive and counteroffensive skills from various punching distances; continuously and effectively, taking into account the correct technical performance requirements characterized by being forceful, rapid, proactive and enduring since the beginning of the game until the end in order to win and achieve higher scores. Training should be designed to be compatible with the requirements of boxing. The boxer should have high physical efficiency during the game so that he can strike the greater number of punches and effectively finish the game.

Muscle strength is one of the most important physical elements for boxers. Boxing is mainly based on the ability of the muscles to contract and expand, as well as working

\footnotetext{
${ }^{1}$ Associate professor at Physical Education \& movement Sciences Dep. College of Education, Qassim University, and sports kinesiology Dep., Faculty of Physical Education, Mansoura University

${ }^{2}$ Associate professor at Physical Education \& movement Sciences Dep. College of Education, Qassim University, and Athletic Training Dep., Faculty of Physical Education, Mansoura University
} 
alternately to perform limb movements. The more powerful are the muscles the more effective are the contractions.

Abul Ela Ahmed Abdel-Fattah (1997) defines muscular balance as the strength of one muscle or muscle group and its correlation to another muscle or other muscle group.(1)

Terzis, G., \& Al ,. (2003) believes that speed distinctive strength exercises for the muscles of the arms; particularly the triceps muscle, as they have a positive impact on the level of technical performance.

The rapid and powerful movements of the boxer lead to stressing the tissues of the body (tendons - muscles - ligaments) and makes them vulnerable to injury. Therefore, strength training increases the connectivity of the tissues connecting the body parts and help preventing injury.

No doubt that rapid motor performance is an important element that help the boxer to win. Speed performance of punches surprise the contender by attacking and speed transition of the various boxing positions, and linking the defense to counter-attack faster than the contender; which is one of the most important elements to win the game. Ismail Hamid (1997) confirms that after using the computer arbitration, modern boxing became more about scoring the most points not harming the contender.

Developed countries in the sport of boxing have realized the importance of the rapid implementation of modified training methods to keep pace with this development to be reflected in the Prompt striking of punches in allowed body parts where punching is permissible; without relying on knock-outs to win. (3) Since there was an urgent need to improve the speed performance of the punches, it became necessary to develop the balanced Muscle strength - particularly, the muscles of the arms. Muscle strength is closely correlated to speed to produce rapid and strong movement.

The researchers' tracking of many local and international championships, and their field expertise in boxing training, they noticed the delay of arms' return while performing straight right and left punches to the defense position during punching the contender; thereby impacting the performance of the punches sequence in terms of the required speed and strength. This leads to the inability of the boxer to score the most points.

Thus the researchers were urged to conduct a survey on a sample of young boxers above (16: less than 19 years old). This showed that there is a weakness in the performance of rapid straight punches due to the imbalance in Muscle strength between flexors and extensor articuars of the elbows and shoulders by different from $(1: 1)$ referred to in most scientific references.

Consequently, the researchers refer to the fact that there are shortcomings in training young boxers, especially in weight training, which focuses on working on the performance of the basic movement of straight punches muscle without focusing on working on the retreating movement of the muscles, resulting in a lack of muscular balance when performing the punches.

Therefore, the present study aimed to identify the effect of Muscle strength training to balance the muscles of the arms and shoulders and some kinematic variables of straight punches. The researchers assumed that the Muscle strength exercises positively affect the muscular balance of the arms and shoulders and some kinematic variables of straight punches. 


\section{Research procedures:}

- Methodology: the experimental approach by using the experimental design for one set of pre and post measurement.

- Place: Boxing gym and the sports movement laboratory in the Faculty of Physical Education at Mansoura University

- Time: The pilot study was conducted pre and post measurements were taken, and the application of Muscle strength training was performed during the preparation period within the training program for boxing players in the period from 31/06/2013 till $3 / 10 / 2013$.

- Research sample: The research sample was chosen intentionally from young boxing players in Mansoura Stadium, i.e. (10) boxing players according to the following table.

Table (1) statistical description of the sample $\mathrm{n}=10$

\begin{tabular}{|c|l|l|c|c|c|c|}
\hline \hline \multirow{2}{*}{ S } & \multirow{2}{*}{$\begin{array}{l}\text { Variable } \\
\text { unit }\end{array}$} & \multicolumn{4}{|c|}{ The experimental group } \\
\cline { 4 - 7 } & & Average & Mediator & Deviation & Skewness \\
\hline \hline 2 & Age & Year & 18.14 & 18.00 & 0.254 & 1.648 \\
\hline 3 & Weight & $\mathrm{Cm}$ & 174.6 & 176 & 4.322 & -1.180 \\
\hline 4 & $\begin{array}{l}\text { Training } \\
\text { Duration }\end{array}$ & $\mathrm{Kg}$ & 67.7 & 67.5 & 9.419 & 0.032 \\
\hline \hline
\end{tabular}

Table (1) shows that the value of Skewness coefficient for the research sample ranged between $(-0.760,0.629)$, and that these values are confined between +3 indicating medium values of research sample before the experiment.

\section{Exploratory study:}

The researchers to conducted an exploratory study in the period from 13/6/2013 till $02 / 07 / 2013$ on a sample of young boxing players from above (16: less than 19 years) outside of the core sample study.

Table (2) significant differences between the averages of measurements of flexors and extensors muscles of the elbow joint

\begin{tabular}{|c|c|c|c|c|c|c|c|c|}
\hline \multirow{2}{*}{$\mathbf{S}$} & \multirow{2}{*}{ Variable } & \multirow{2}{*}{$\begin{array}{l}\text { Average } \\
\text { flexors }\end{array}$} & \multirow{2}{*}{$\begin{array}{c}\text { Average } \\
\text { extensors }\end{array}$} & \multicolumn{2}{|c|}{ Positive Ranks } & \multicolumn{2}{|c|}{ Negative ranks } & \multirow{2}{*}{$\begin{array}{l}(Z)- \\
\text { Value }\end{array}$} \\
\hline & & & & Average & Total & Average & Total & \\
\hline 1 & $\begin{array}{l}\text { Right } \\
\text { elbow }\end{array}$ & 21.46 & 27.78 & 3.00 & 15.00 & - & - & 2.032 \\
\hline 2 & Left elbow & 19.80 & 27.54 & 3.00 & 15.00 & - & - & 2.023 \\
\hline 3 & $\begin{array}{l}\text { Both } \\
\text { Elbows }\end{array}$ & 44.14 & 49.66 & 3.00 & 15.00 & - & - & 2. 0.32 \\
\hline
\end{tabular}

* ( Z ) Value at the 0.05 level $= \pm$ r.96

Table (2) shows the presence of statistically significant differences in the pre measurement between the average strength of extensors and flexors of the elbow joint in 
favor of the flexors, where the calculated value of the " $\mathrm{Z}$ " is greater than the value of " $\mathrm{Z}$ " in the table at the abstract level (0.05). The ratio between the mean strength of extensors and the strength of elbow flexors of the right and left elbows consequently are: (0.77: 1) (0.72: 1) (0.88: 1). These ratios differ from the ratios referred to in scientific references on the elbow joint, namely, (1: 1), which indicates the presence of muscle imbalance.

\section{Research Implementation:}

\section{Measurements \& Tests:}

Pre measurements were taken during the period from 4-6/07/2013 in the boxing gym, and the sports movement laboratory in the Faculty of Physical Education, Mansoura University, as follows:

- Height \& weight.

- Measuring the balance in Muscle strength: muscular balance was measured using the One Repetition Maximum (1RM) test where a player lifts a maximum weight at once. (27), (8)

- Endurance test: striking straight punches on the punching bag (30 sec.) for each arms. (5)

- Muscular strength of the arms: throwing the Medical ball $(3 \mathrm{~kg})$ to the furthest distance by the left and right hand. (4)

- Kinematic measurements: (punching time - Return time - the total time of the punch) for each punch, (angular displacement - angular velocity) for each joint of the elbow and shoulder.

\section{Research Tools and equipments:}

- Restameter to measure height

- Scale to measure weight

- A measuring tape

- Medical balls $(3 \mathrm{~kg})$

- Stopwatch (.01 part of the second)

- Boxing gloves - boxing bags - variable free weights

- Elastic tapes

- Kinetic response measuring device

- 2 High-speed video camera (SportsCam 250 frame/sec.)

- Kinetic analysis unit (Simi Motion)

Kinetic analysis: 3D kinematography analysis process using the kinetic analysis (Simi Motion) with (2) High-speed video camera (SportsCam 250 frame/sec.). Conducting the kinetic analysis led directly to kinematic variables (punching time - Return time - the total time of the punch) for each punch, (angular displacement - angular velocity) for each joint of the elbow and shoulder.

\section{The training program:}

The implementation of the training program "is divided into two parts" with the research sample in the Olympic Village in Mansoura University for a period of 12 weeks from 08/07/2013 to 30/09/2013. The training modules were (6) modules per week; i.e. (3) (weightlifting) modules and (3) (Special strength) modules. Each module is about (75-135 minutes). Degrees of endurance were distributed on the training weeks where the endurance average was between (50-74\%), higher endurance was between (75-84\%) and maximum endurance was between (85: to the limits of the player 100\%), and the endurance cycle was (1: 1). 
The program was divided into three phases:

- General preparation for (3) weeks exercises to develop general strength "the power of endurance."

- Setup and for (5) weeks to develop special strength characterized by speed and maintaining the endurance level.

- Pre competition for (4) weeks of using of offensive and defensive skills which are performed in the form of rounds. The training is on the equipments and tools that are similar to the positions of play.

- The application of muscle strength training (endurance power - speed power) by focusing on the muscles of the arms in a balanced manner between the strong working muscles and weak muscles in the basic movement and the returning movement of resilience during the performance of punches, and these exercises are as follows:

1. From standby position boxer stands facing the wall where an elastic cord is installed and linked with the wrist, and then he performs the back movement of the straight punch, the rubber cord becomes taut and then the punching movement is repeated and so does the performance (left hand - right hand).

2. The same position with the installation of another rubber cord to the back of the shoulder and holding the fist, at the punching performance, the cord at the shoulders becomes taut. However, in repeating the performance, the rubber cord installed to the wall is tightened in the back movement.

3. From the standby position - Dumbbells are in hands, cord rubber belted to the wrist and installed in the fronting wall to perform straight punches.

4. From the standby position - weights are tied to the arm and rubber cord tied to the wrist and installed to the wall, and straight punches are performed.

Note: You can increase the resistance of back movement to balance muscle strength by doubling the rubber cord installed in the wall and that:

- Install more than one cord into the wall.

- Increase the weight of the Dumbbells.

- Controlling the segments of iron weights inside the weightlifting walls.

The training program aims to develop distinctive power as quickly and carry own boxers power next to the rest of the fitness of general and special physical elements as well as the skill and tactical setup, using the tools of assistance and training for the different training packages whether individual training or marital, taking into account individual differences. The program also seeks to achieve a balance of the extensor muscles of the flexors and the elbow joint and shoulders for the sake of performing straight punches muscle work (performance time - return time) and using some selected exercises to develop muscle balance.

Post-measurements: Its was conducted after end of training program on the application of the research sample in the period of 1-3 / 10/2013. The Measurements were taken in the same sequence to be compared to the pre measurements.

Statistical Analysis: The researchers used the Statistics software (Excel \& SPSS) for processing the data of the research variables, as follows: (average - Wilcoxon test -MannWhitney test- improvement ratio) 


\section{Results:}

Table (3) significant differences among the middle-dimensional measurements of muscle strength Holding and the strength of the extensor muscles of the elbow joint

\begin{tabular}{|c|c|c|c|c|c|c|c|c|}
\hline \multirow[b]{2}{*}{$\mathbf{S}$} & \multirow{2}{*}{$\begin{array}{l}\text { The } \\
\text { variable } \\
\text { name }\end{array}$} & \multirow{2}{*}{$\begin{array}{c}\text { Average } \\
\text { flexors }\end{array}$} & \multirow{2}{*}{$\begin{array}{l}\text { Average } \\
\text { extensor } \\
\text { muscles }\end{array}$} & \multicolumn{2}{|c|}{ Ranks positive } & \multicolumn{2}{|c|}{ Negative ranks } & \multirow{2}{*}{$\begin{array}{c}\text { Value } \\
(\mathbf{Z})\end{array}$} \\
\hline & & & & $\begin{array}{c}\text { Average } \\
\text { grade }\end{array}$ & $\begin{array}{l}\text { Total } \\
\text { ranks }\end{array}$ & $\begin{array}{c}\text { Average } \\
\text { grade }\end{array}$ & $\begin{array}{l}\text { Total } \\
\text { ranks }\end{array}$ & \\
\hline 1 & $\begin{array}{l}\text { Right } \\
\text { elbow }\end{array}$ & 32.05 & 31.90 & 5.10 & 25.5 & 4.88 & 19.50 & 0.362 \\
\hline 2 & Left elbow & 32.3 & 32.22 & 4.75 & 19.00 & 4.25 & 17.00 & 0.888 \\
\hline 3 & $\begin{array}{l}\text { Elbows } \\
\text { together }\end{array}$ & 55.00 & 55.98 & 5.5 & 25.00 & 6.00 & 30.00 & 0.255 \\
\hline
\end{tabular}

* ( Z ) Value at the 0.05 level = 1.96

Shown in Table (3) No significant differences statistically in the dimensional measurement between the Mediterranean flexors and extensor muscle strength of elbow joint for the benefit of the extensor muscles, where the value of " $Z$ "Less than the calculated value" $\mathrm{Z}$ "Driven at the moral level of 0.05 , and the ratio between the mean flexors and the strength of the extensor muscle strength of the right elbow and left the facility and elbows together is (1: 1)

Table (4) significant differences among the middle-dimensional measurements Performance time to time and see total time

\begin{tabular}{|c|c|c|c|c|c|c|c|c|}
\hline \multirow[b]{2}{*}{$\mathbf{S}$} & \multirow{2}{*}{$\begin{array}{l}\text { The variable } \\
\text { name }\end{array}$} & \multirow{2}{*}{$\begin{array}{c}\text { Average } \\
\text { time } \\
\text { Performance }\end{array}$} & \multirow{2}{*}{$\begin{array}{c}\begin{array}{c}\text { Average } \\
\text { time }\end{array} \\
\text { Return }\end{array}$} & \multicolumn{2}{|c|}{ Ranks positive } & \multicolumn{2}{|c|}{ Negative ranks } & \multirow{2}{*}{$\begin{array}{l}\text { Value } \\
(\mathbf{Z})\end{array}$} \\
\hline & & & & $\begin{array}{c}\text { Average } \\
\text { grade }\end{array}$ & $\begin{array}{l}\text { Total } \\
\text { ranks }\end{array}$ & $\begin{array}{c}\text { Average } \\
\text { grade }\end{array}$ & $\begin{array}{l}\text { Total } \\
\text { ranks }\end{array}$ & \\
\hline 1 & $\begin{array}{l}\text { The rectum of } \\
\text { the left }\end{array}$ & 0.134 & 0.137 & 11.5 & 24.5 & 2.88 & 11.5 & 0.922 \\
\hline 2 & Total time & \multicolumn{2}{|c|}{0.271} & 5.5 & 55.00 & - & - & 2.803 \\
\hline 3 & Right straight & 0.213 & 0.218 & 4.62 & 37.00 & 9.00 & 18.00 & 0.970 \\
\hline 4 & Total time & \multicolumn{2}{|c|}{0.431} & 5.5 & 55.00 & - & - & 2.803 \\
\hline
\end{tabular}

It is seen from the table (4) There are no statistically significant differences in the dimensional measurement between the average performance time and time back to the straight punches left and right, where the value of " $\mathrm{Z}$ "Less than the calculated value" $Z$ "When the tabular moral level of 0.05 with a statistically significant differences between the average total time to perform punch. 
Table (5) significant differences between the averages of tribal dimensional measurements experimental group of muscle strength Holding and the strength of the extensor muscles of the elbow joint and shoulders.

$\mathrm{n}=10$

\begin{tabular}{|c|c|c|c|c|c|c|c|c|c|}
\hline \multirow[b]{2}{*}{$\mathbf{S}$} & \multirow[b]{2}{*}{ Variables } & \multirow[b]{2}{*}{ Measurements } & \multirow{2}{*}{$\begin{array}{c}\text { Average } \\
\text { Pre - } \\
\text { test }\end{array}$} & \multirow{2}{*}{$\begin{array}{c}\text { Average } \\
\text { Post - } \\
\text { test }\end{array}$} & \multicolumn{2}{|c|}{ Ranks positive } & \multicolumn{2}{|c|}{ Negative ranks } & \multirow{2}{*}{$\underset{(\mathrm{z})}{\text { Value }}$} \\
\hline & & & & & $\begin{array}{c}\text { Average } \\
\text { Ranks }\end{array}$ & $\begin{array}{c}\text { Total } \\
\text { Ranks }\end{array}$ & $\begin{array}{c}\text { Average } \\
\text { Ranks }\end{array}$ & $\begin{array}{c}\text { Total } \\
\text { Ranks }\end{array}$ & \\
\hline \multirow[b]{2}{*}{1} & \multirow[b]{2}{*}{$\begin{array}{l}\text { The right } \\
\text { elbow }\end{array}$} & Flexors & 21.61 & 32.05 & 5.5 & 55.0 & $\begin{array}{l}- \\
\end{array}$ & - & 2.805 \\
\hline & & $\begin{array}{l}\text { Extensor } \\
\text { muscles }\end{array}$ & 27.76 & 31.9 & 5.5 & 55.0 & - & - & 2.821 \\
\hline \multirow[b]{2}{*}{2} & \multirow[b]{2}{*}{$\begin{array}{l}\text { Left } \\
\text { elbow }\end{array}$} & Flexors & 20.61 & 32.30 & 5.5 & 55.0 & - & - & 2.869 \\
\hline & & $\begin{array}{l}\text { Extensor } \\
\text { muscles }\end{array}$ & 27.71 & 32.22 & 5.5 & 55.0 & - & - & 2.821 \\
\hline \multirow[b]{2}{*}{3} & \multirow[b]{2}{*}{$\begin{array}{l}\text { Elbows } \\
\text { together }\end{array}$} & Flexors & 44.36 & 55.00 & 5.5 & 55.0 & - & - & 2.810 \\
\hline & & $\begin{array}{l}\text { Extensor } \\
\text { muscles }\end{array}$ & 49.65 & 54.98 & 5.5 & 55.0 & - & - & 2.805 \\
\hline \multirow[b]{2}{*}{4} & \multirow{2}{*}{$\begin{array}{l}\text { The } \\
\text { ability of } \\
\text { muscle to } \\
\text { arms }\end{array}$} & Right & 8.33 & 11.60 & 5.5 & 55.0 & - & - & 2.812 \\
\hline & & Left & 7.03 & 9.45 & 5.5 & 55.0 & - & - & 2.821 \\
\hline \multirow[b]{2}{*}{5} & \multirow{2}{*}{$\begin{array}{l}\text { Endurance } \\
\text { force } \\
\text { Of the } \\
\text { arms }\end{array}$} & Right & 51.20 & 62.5 & 5.5 & 55.0 & - & - & 2.812 \\
\hline & & Left & 69.9 & 89.20 & 5.5 & 55.5 & - & - & 2.805 \\
\hline
\end{tabular}

* ( Z ) Value at the 0.05 level = 1.96

Seen from the table (5) and no statistically significant differences between the mean tribal measurements dimensional experimental group in favor of telemetric at the level (0.05) in the flexors and extensor muscles strength of the elbow joint the right and the left the facility and elbows together and the ability of the shoulders and carry power for the benefit of telemetric This is confirmed by value $\mathrm{Z}$ Driven.

Table (6) Percentage of improvement flexors and extensor strength of articular facility and shoulders.

\begin{tabular}{|c|c|c|c|c|c|c|}
\hline $\mathbf{S}$ & \multicolumn{2}{|c|}{ Test Name } & $\begin{array}{l}\text { Average } \\
\text { Pre - test }\end{array}$ & $\begin{array}{c}\text { Average } \\
\text { Post - test }\end{array}$ & $\begin{array}{c}\text { Medium } \\
\text { Pre / post - } \\
\text { test }\end{array}$ & $\begin{array}{c}\text { Ratio } \\
\text { improvement } \\
\%\end{array}$ \\
\hline \multirow[b]{2}{*}{1} & \multirow{2}{*}{$\begin{array}{l}\text { The right } \\
\text { elbow }\end{array}$} & Flexors & 21.61 & 32.05 & 10.44 & 48.3 \\
\hline & & $\begin{array}{l}\text { Extensor } \\
\text { muscles }\end{array}$ & 27.76 & 31.9 & 4.11 & 14.9 \\
\hline \multirow[b]{2}{*}{2} & \multirow[b]{2}{*}{ Left elbow } & Flexors & 20.61 & 32.30 & 11.69 & 56.7 \\
\hline & & $\begin{array}{l}\text { Extensor } \\
\text { muscles }\end{array}$ & 27.71 & 32.22 & 4.51 & 16.3 \\
\hline \multirow[b]{2}{*}{3} & \multirow[b]{2}{*}{$\begin{array}{l}\text { Elbows } \\
\text { together }\end{array}$} & Flexors & 44.36 & 55.00 & 10.64 & 24.0 \\
\hline & & $\begin{array}{l}\text { Extensor } \\
\text { muscles }\end{array}$ & 49.65 & 54.98 & 5.33 & 10.7 \\
\hline \multirow[b]{2}{*}{4} & \multirow{2}{*}{$\begin{array}{l}\text { The ability } \\
\text { of muscle } \\
\text { to arms }\end{array}$} & Right & 8.33 & 11.60 & 3.27 & 39.3 \\
\hline & & Left & 7.03 & 9.45 & 2.42 & 34.4 \\
\hline \multirow[b]{2}{*}{5} & \multirow{2}{*}{$\begin{array}{l}\text { Carry the } \\
\text { force } \\
\text { arms }\end{array}$} & Right & 51.20 & 62.5 & 11.3 & 22.1 \\
\hline & & Left & 69.9 & 89.20 & 19.3 & 27.6 \\
\hline
\end{tabular}


Seen from the table (6) that the highest percentage of improvement was the muscles Holding Facility The left and amount (56.7\%) while the lowest rate of improvement of the extensor muscles of the two facilities together and amount $(10.7 \%)$.

Table (7) significant differences between the averages of tribal dimensional measurements some of the variables Kinematic

\begin{tabular}{|c|c|c|c|c|c|c|c|c|c|}
\hline \multirow{2}{*}{$\mathbf{S}$} & \multirow{2}{*}{\multicolumn{2}{|c|}{ Test Name }} & \multirow{2}{*}{$\begin{array}{l}\text { Average } \\
\text { Pre - test }\end{array}$} & \multirow{2}{*}{$\begin{array}{l}\text { Average } \\
\text { Post - test }\end{array}$} & \multicolumn{2}{|c|}{ Ranks positive } & \multicolumn{2}{|c|}{ Negative ranks } & \multirow{2}{*}{$\underset{(\mathrm{z})}{\text { Value }}$} \\
\hline & & & & & $\begin{array}{c}\text { Average } \\
\text { Ranks }\end{array}$ & $\begin{array}{c}\text { Total } \\
\text { Ranks }\end{array}$ & $\begin{array}{c}\text { Average } \\
\text { Ranks }\end{array}$ & $\begin{array}{c}\text { Total } \\
\text { Ranks }\end{array}$ & \\
\hline \multirow{7}{*}{1} & \multirow{7}{*}{ 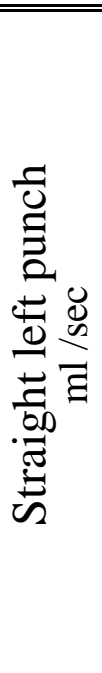 } & $\begin{array}{l}\text { Punching } \\
\text { time }\end{array}$ & 0.161 & 0.134 & - & - & 5.5 & 55.0 & 2.823 \\
\hline & & $\begin{array}{l}\text { Return } \\
\text { time }\end{array}$ & 0.174 & 0.137 & - & - & 5.5 & 55.0 & 2.805 \\
\hline & & $\begin{array}{l}\text { Total } \\
\text { time }\end{array}$ & 0.335 & 0.271 & - & - & 5.5 & 55.0 & 2.803 \\
\hline & & $\begin{array}{l}\text { Elbow } \\
\text { angle }\end{array}$ & 109.3 & 133.3 & 5.5 & 55.0 & - & - & 2.807 \\
\hline & & $\begin{array}{l}\text { Angular } \\
\text { velocity } \\
\text { of Elbow }\end{array}$ & 307.4 & 345.7 & 5.5 & 55.0 & - & - & 2.805 \\
\hline & & $\begin{array}{l}\text { Shoulder } \\
\text { angle }\end{array}$ & 60.6 & 73.8 & 5.5 & 55.0 & - & - & 2.821 \\
\hline & & $\begin{array}{l}\text { Angular } \\
\text { velocity } \\
\text { of } \\
\text { Shoulder }\end{array}$ & 204.7 & 240.7 & 5.5 & 55.0 & - & - & 2.803 \\
\hline \multirow{7}{*}{2} & \multirow{7}{*}{ 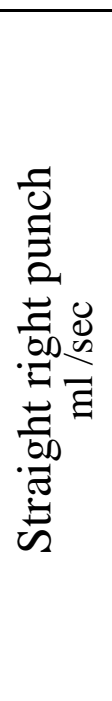 } & $\begin{array}{l}\text { Punching } \\
\text { time }\end{array}$ & 0.260 & 0.213 & - & - & 5.5 & 55.0 & 2.807 \\
\hline & & $\begin{array}{l}\text { Return } \\
\text { time }\end{array}$ & 0.292 & 0.235 & - & - & 5.5 & 55.0 & 2.807 \\
\hline & & $\begin{array}{l}\text { Total } \\
\text { time }\end{array}$ & 0.552 & 0.449 & - & - & 5.5 & 55.0 & 2.805 \\
\hline & & $\begin{array}{l}\text { Elbow } \\
\text { angle }\end{array}$ & 125.3 & 151.5 & 5.00 & 45.00 & - & - & 2.677 \\
\hline & & $\begin{array}{l}\text { Angular } \\
\text { velocity } \\
\text { of Elbow }\end{array}$ & 428.9 & 502.4 & 5.5 & 44.00 & 1.00 & 1.00 & 2.547 \\
\hline & & $\begin{array}{l}\text { Shoulder } \\
\text { angle }\end{array}$ & 70.4 & 84.7 & 5.5 & 55.0 & - & - & 2.807 \\
\hline & & $\begin{array}{l}\text { Angular } \\
\text { velocity } \\
\text { of } \\
\text { Shoulder }\end{array}$ & 335.4 & 401.2 & 5.5 & 55.0 & - & - & 2.803 \\
\hline
\end{tabular}

* ( Z ) Value at the 0.05 level $=\mathrm{r} .96$

Seen from the table (7) and no statistically significant differences between the mean tribal measurements and a posteriori the control group in favor of dimensional measurement at the level (0.05) in all of time punching and time reference and the total time and the angle of the facility and the angular velocity of straight left and right punch tests. 
Table (8) Percentage of improvement in the experimental group for some variables Kinematic.

\begin{tabular}{|c|c|c|c|c|c|c|}
\hline $\mathbf{M}$ & \multicolumn{2}{|c|}{ Test Name } & $\begin{array}{l}\text { Average } \\
\text { Pre - test }\end{array}$ & $\begin{array}{c}\text { Average } \\
\text { Post - test }\end{array}$ & $\begin{array}{c}\text { Medium } \\
\text { Pre / post - test }\end{array}$ & $\begin{array}{c}\text { Ratio } \\
\text { Improvement } \\
\%\end{array}$ \\
\hline \multirow{7}{*}{1} & \multirow{7}{*}{ 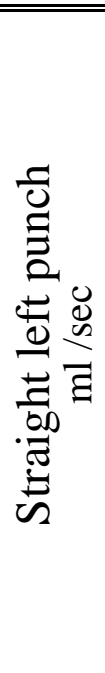 } & $\begin{array}{l}\text { Punching } \\
\text { time }\end{array}$ & 0.161 & 0.134 & 0.027 & 16.5 \\
\hline & & $\begin{array}{l}\text { Return } \\
\text { time }\end{array}$ & 0.174 & 0.137 & 0.039 & 20.9 \\
\hline & & $\begin{array}{l}\text { Total } \\
\text { time }\end{array}$ & 0.335 & 0.271 & 0:06 4 & 19.1 \\
\hline & & $\begin{array}{l}\text { Elbow } \\
\text { angle }\end{array}$ & 109.3 & 133.3 & 24.0 & 22 \\
\hline & & $\begin{array}{l}\text { Angular } \\
\text { velocity } \\
\text { of Elbow }\end{array}$ & 307.4 & 345.7 & 38.3 & 12.5 \\
\hline & & $\begin{array}{l}\text { Shoulder } \\
\text { angle }\end{array}$ & 60.6 & 73.8 & 13.2 & 21.8 \\
\hline & & $\begin{array}{l}\text { Angular } \\
\text { velocity } \\
\text { of } \\
\text { Shoulder }\end{array}$ & 204.7 & 240.7 & 36 & 17.6 \\
\hline \multirow{7}{*}{2} & \multirow{7}{*}{ 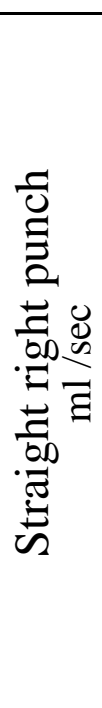 } & $\begin{array}{l}\text { Punching } \\
\text { time }\end{array}$ & 0.260 & 0.213 & 0.046 & 17.8 \\
\hline & & $\begin{array}{l}\text { Return } \\
\text { time }\end{array}$ & 0.292 & 0.235 & 0.057 & 19.5 \\
\hline & & $\begin{array}{l}\text { Total } \\
\text { time }\end{array}$ & 0.552 & 0.448 & 0.103 & 18.8 \\
\hline & & $\begin{array}{l}\text { Elbow } \\
\text { angle }\end{array}$ & 125.3 & 151.5 & 26.2 & 20.9 \\
\hline & & $\begin{array}{l}\text { Angular } \\
\text { velocity } \\
\text { of Elbow }\end{array}$ & 428.9 & 502.4 & 73.5 & 17.1 \\
\hline & & $\begin{array}{l}\text { Shoulder } \\
\text { angle }\end{array}$ & 70.4 & 84.7 & 14.3 & 20.3 \\
\hline & & $\begin{array}{l}\text { Angular } \\
\text { velocity } \\
\text { of } \\
\text { Shoulder }\end{array}$ & 335.4 & 401.2 & 65.8 & 19.6 \\
\hline
\end{tabular}

Table (8) shows that the highest percentage of improvement was to test the facility and the angle of (22\%), While the lowest rate of speed improvement left corner of the facility And amount $(16.5 \%)$ To punch straight left.

\section{Discussion of Results}

table (3) shows that there are no statistically significant differences in post measurement between the average power of extensors and flexors of the elbow joint in favor of the flexors, where the value of the "Z" calculated is less than the value of "Z" Driven at the moral level of 0.05 , and the ratio between the mean power of extensors and the strength of flexors the elbow joint the right and the left the facility and elbows together is (1: 1) and this confirms the absence of significant differences in muscle strength between extensors and the extensor of the elbow joint and the left and right elbows together. which shows the balance in muscle strength between extensors and the extensor of the elbow 
joint. This is consistent with what referred to by scientists in determining the balance ratios muscle around the elbow joint between the extensors and the extensor, namely, (1: 1)

The researchers believe that change to the positive impact of the training muscle strength that has been applied to the study sample, in line with what was said by Mohamed Abdel Dayem et al. (1993) that muscle groups training must be in isolation until a state of muscle imbalance does not occur.

The consistent results of this study with the results of each of Kamal Abdel Jaber 2000 studies m, Ahmed Salah, 2000 , Yasin Ahmed, 2002 , Mostafa Amin 2006 , and Mohamed Zakaria 2010 that the training programs as well as workouts, whether with or without using tools leads to physical attributes for the development of boxers with or without boxing equipment and instruments.

As can be seen from the table (4) that there are no significant differences statistically in post measurement between the average performance time and time reference punched straight left and right, where the value of the " $\mathrm{Z}$ " calculated in performance time to punch straight left 0.922 and the value of the value of " $Z$ " calculated at the time of Return to punch right straight 0.970 , while the value of " $Z$ " Driven 1.96 at the moral level of 0.05 with a statistically significant differences between the average total time to perform punch. which indicates the absence of significant differences between the performance time and time reference punched straight. This was due researchers this change to achieve a balance in muscle strength between extensors and the extensor of the elbow joint and shoulders through the implementation of the training program on the study sample, which led to the improvement of resilience speed of movement. This is in line with what referred to the Mufti Ibrahim (1998) that the muscle power of the relevant factors as fast as it is the higher power muscle whenever possible to overcome the resistances greater the speed. (13)

It is clear from Table (5), (6) the existence of differences of significance for the post measurement at the level (0.05) in the strength of extensors and the extensor of the elbow joint left and right and elbows together and the ability muscle of the arms and carry the force of arms was limited value $(Z)$ favoritism between $(2.805,2.869)$ while the $(Z)$ Driven (1.96) as well as the percentage of increase ranging between $(10.7 \%, 56.7 \%)$ and this is what consolation researchers to the impact of the pilot program, which depends on regular training, as well as the number of training units, which amounted to (6) units by training a week (3) items (for weightlifting exercises) and (3) items (for strength training). As far back as the researchers provide the sample level in muscle strength tests to the impact of the training program, which contains the different training packages aimed at muscle strength development whether individual or marital training as well as training on the instruments and tools that are similar to the positions of play, taking into account individual differences loads and also to choose the exercises Depending on the muscle contraction of muscle which has contributed significantly to the improvement of these variables in a sample study.

This is consistent with the results of each of Michel A.Hartle 1996 studies, David Lipman 1998, Wael Kandil 2001 and Hani El-Deeb 2003, Mohammed Zakaria 2010 that the anti muscle development when players to Besides the basic driving muscles it is very important to achieve muscular balance.

Explains Table (7), (8) the presence of significant differences in favor of the post measurement at the level (0.05) in the variables kinematic under study to punch straight left and right, a punching time, time reference, time kidney to punch, the corners of the facility 
and shoulder and angular velocity for each of the articular the facility and shoulder where the value $(Z)$ calculated higher than the Tabulated value $( \pm 1.96)$ at the moral level of 0.05 where the average punching $0.134 \mathrm{w}$ time, time reference $0.137 \mathrm{~W}$, Time kidney to punch $0.271 \mathrm{~W}$, the angle of attachment 133.3 degrees, and the angle of the shoulder 73.8 degrees, While the angular velocity of the elbow joint $345.7^{\circ} / \mathrm{s}$, and the angular velocity of the shoulder joint $240.7^{\circ} / \mathrm{s}$ for the straight left punch. While the average punching $0.213 \mathrm{w}$ time, time reference $0.235 \mathrm{~W}$, Time kidney to punch $0.448 \mathrm{w}$, annex angle 151.5 degrees, and the angle of the shoulder 84.7 degrees, while the angular velocity of the elbow joint $502.4^{\circ} / \mathrm{s}$, and the angular velocity of the shoulder joint $401.2^{\circ} / \mathrm{s}$ for right straight punch.

This confirms that the percentage of improvement where she was when punching a time of $16.5 \%$, the time of return of $20.9 \%$, Time kidney to punch $19.1 \%$, annex $22 \%$ angle, and the angle of the shoulder $21.8 \%$, while the corner speed of the elbow joint of $12.5 \%$, and the angular velocity of the shoulder joint $17.6 \%$, to left straight punch. While the percentage of improvement when punching $17.8 \%$ time, time back $19.5 \%$, Time kidney to punch $18.8 \%$, angle attachment $20.9 \%$, and the angle of the shoulder $20.3 \%$, while the angular velocity of the elbow joint $17.1 \%$, and the angular velocity of the shoulder joint $19.6 \%$ to right straight punch.

The results in table (8) shows that the rate of progress for improvement in each of the angular displacement of the articular facility and shoulder more than the angular velocity of the articular shoulder and elbow is normal as a result of increasing the effectiveness of physical performance resulting from the achievement of the muscular balance. It also emphasizes that increasing the proportion of improvement in the time reversed in punching each of the left and right punching time, in line with the results of Hamada Habib Mustafa Nasr 2008 study , Hamada A. Habib, 2010 , Mohammed Zakaria 2010 .

As can be shown from the results of table (7) that the improvement ratios in the angular velocity variable to the elbow joint when performing right punch biggest of them when performing left punch due to the stability of punching distance and increase the range of the right punch compared to the left hand, as well as the results of the angular velocity of the shoulder joint in his right punches. The biggest of them left for the elbow joint as a result of increasing the degree of freedom of the shoulder joint, compared hinge attachment. The consistent results of the study with Hamada Habib 2005 (6) that control the peripheral joints (arms and legs) at least from the detailed high to the following detailed him, that control the shoulder joint is greater than control Detailed facility. The Control least increase range of motion, the results of the study demonstrated that an increase in the percentage improvement in the angular velocity of the articular shoulder and elbow in the right punches compared to the left hand, because of the larger role played by articular shoulder and torso in the performance of the right punch.

This is in line with Hamada Habib 2005 to achieve the goal of the movement of what is done by motor integration between the common joints movements at work and the forces exerted common for members of the work, as well as integration between the joints movements and effort.

In the opinion researchers through those results that balance the muscular strength of the muscles Holding and extensor elbow joint through effective training muscle strength which is working in the direction of working muscle to perform straight punches, which 
have had the most improvement in muscle strength of the elbow joint in a balanced effect, resulting in it to improve the performance time and time back to the straight punches.

\section{Conclusions:}

Muscle strength training led to achieve balance in muscle strength of the extensors and flexors muscles of the elbow joint and shoulders. Where the percentage of power to force extensors flexors of the elbow joint and the left and right elbows together (1: 1).

High rates of improvement ratios between pre measurement means and post to the research sample in muscle strength of the flexors, reaching $48.3 \%$ of the flexor muscles of the right of the elbow, $(56.7 \%)$ of the muscles flexors of the left elbow, $(24.0 \%)$ of the muscles flexors of the two elbows together.

Training muscle power and strength led to improved kinematic variables under study to straight left and right punches.

\section{Recommendations :}

following :

In light of the outcome of the research, the researchers recommends that the

- The use of strength training muscle balanced in different proportions of the muscles holding the extensor arms and according to the strength of each muscle to improve the balance muscle among themselves within the training programs for players boxing at training on straight punches, due to its effectiveness in improving the performance of punches (punching - Back).

- Use (1RM) test as an indicator to measure the strength of the forces of the muscles of the arms (flexors - extensors)

- Interest in identifying the most important kinematic variables needed to improve before the start of the preparation of training programs for players boxing content. As well as measurements power and kinetic analysis during various training periods.

\section{References:}

- Abdul Aziz Tiger, Nariman al-Khatib(2007): Muscle power design and power planning the training season programs, professors of sports book, Cairo p.232 (In Arabic).

- Abu Ela Ahmed Abdel Fattah .(1997): Sports Training - physiological foundations, the Arab Thought House, Nasr City, . p.146 (In Arabic).

- Abdulaziz Hamada Habib (2005): Track Byumkanikih selected variables during the construction of kinetic program, PhD, Faculty of Physical Education for Boys in Cairo, Helwan University, p.75 (In Arabic).

- Ahmed Mohammed Salahuddin(2000): Impact exercises force on the performance skills of the boxers speed, unpublished Master Thesis, Faculty of Physical Education Benin, Helwan University, p.66 (In Arabic).

- Cordes, K., (2000) : www.reasons to strength train for boxing. Com.

- David Lipman (1998): http;// www. physical evidence. com balancing imbalance htm, . 
- Fabio, C., (2004) : function training for sports, Human Kinetics: Champaign IL, England,.pp27 .

- Hamada A. Habib (2010) : Time-Series Analysis through Motor Programming for Sequence Punches,

- Hamada Habib, Mustafa Nasr (2008) : Locomotor balance development on the time structure of the inter punching and effective performance skills of boxers effect, research published Third International Scientific Conference "development of educational curricula in the light of recent trends and the need for the labor market," the Faculty of Physical Education for Girls - Zagazig University, March , (In Arabic).

- Hany El-Deeb(2003) : The impact of a training program for muscle strength to improve muscle balance, unpublished $\mathrm{PhD}$ thesis, Faculty of Physical Education Sadat, Menoufia University, p.87 (InArabic)..

- Hossam Refky (1993) : Boxing, Egyptian Renaissance Library, Cairo, 1993(InArabic)

- Ismail Hamid(1997) : Law and Arbitration computer in boxing, happiness house for printing, Cairo, (InArabic).

- Ismail Hamid, Abdelaziz Ghoneim, Diaa Azab, Atef Mgaroy(2002) : Boxing (education, training and management), happiness house, Cairo, (In Arabic).

- Kamal Abdel Jaber (2000) : Muscle work program Aloazotona effect for the development of muscle power for some punches with boxers, unpublished $\mathrm{PhD}$ thesis, Faculty of Physical Education, Assiut University, (InArabic).

- Mohamed Abdel Dayem, Medhat Saleh, Tariq Qattan Shoukry(1993) : Physical preparation and training weightlifting training programs, 1st Floor, Al-Ahram Press, Cairo, (InArabic).

- Mohamed Zakaria (2010): A training program to balance the muscle power of the extensor muscles of the Holding and the elbow joint to the boxers and its impact on the performance of straight punches speed, unpublished $\mathrm{PhD}$ thesis, Faculty of Physical Education, Sports, Tanta University, p.119 (InArabic).

- Mostafa Amin (2006): The impact of the proposal for the development of distinctive strength training program as fast and accurate performance skills on the effectiveness of the boxers, unpublished Master Thesis, Faculty of Physical Education - Mansoura University, p.95, (InArabic).

- Michel A .hartle(1996) : Overtraining / Muscular imbalance American Journal of sports Medicine committee, 111 ,.

- Mufti Ibrahim (1998): Modern sports training, planning, implementation and leadership, i 1, Dar Arab Thought(InArabic).

- Nader Naeem (2002): The impact of the use of some special boxing workouts to increase the number of pay punches, unpublished Master Thesis, Faculty of Physical Education for Boys, Alexandria University, (InArabic).

- O’Shea, J.P. (1976) : Scientific principles and methods of strength fitness. Boston, Reading (P 24), MA: Addison Wesley. 
- Terzis,G., Georgiadis.G., Vassiliadou, E., Manta, B.,(2003) : Relationship between shot put performance and triceps brachii fiber type composition and power production, European Journal of Applied Physiology, Volume 90, Issue 1-2 September. pp . 10 15 .

- Tiana Weiss, Jerica Kreitinger, Hilary Wilde, Chris Wiora, Michelle Steege Lance Dalleck, Jeffrey Janot ., (2010) : Effect of Functional Resistance Training on Muscular Fitness Outcomes in Young Adults, J Exerc Sci Fit . Vol 8 . No 2 .pp 113122

- Thomas R. Baechle‘Roger W. Earle (2008) : Essentials of Strength Training and Conditioning 'National Strength \& Conditioning Association (U.S.), Human Kinetics.

- Wael Kandil(2001) : Proposed training program for the development of balance in muscle strength squash players, unpublished $\mathrm{PhD}$ thesis, Faculty of Physical Education for Boys pyramid, Helwan University, P.89 (InArabic).

- Yahya EL Hawi (2002) : Boxing foundations of theory - scientific Arab Center for Publishing - applications., P.51 (InArabic).

-Yasen Ahmed Yasen(2000): The players boxing training program for the elements of fitness own in light of the expected goals, unpublished $\mathrm{PhD}$ thesis, Faculty of Physical Education for Boys, Helwan University, P.77 (InArabic). 